\title{
Therapeutic potential of Commiphora molmol extract loaded on chitosan nanofibers against experimental cryptosporidiosis
}

Article

\author{
Azza M Fahmy ${ }^{1}$, Zeinab H Fahmy ${ }^{1}$, Eman A Aly ${ }^{1}$, Amal M Elshenawy ${ }^{1}$, Eman A El- \\ Wakil $^{2}$
}

Parasitology Laboratory, Department of Immunology and Drug Evaluation ${ }^{1}$ and Medicinal Chemistry Laboratory², Theodor Bilharz Research Institute, Imbaba, Giza, Egypt

\begin{abstract}
Background: Cryptosporidium is a life-threatening intestinal pathogen in immunocompromised patients. Currently, there is no entirely successful drug against cryptosporidiosis. Several reports utilizing nanotechnology combined with herbal medicine were published to evaluate its efficacy in treatment of intestinal pathogens.

Objectives: To evaluate the anti-cryptosporidial efficacy of Commiphora molmol extract and its conjugation with chitosan nanofibers (CsNFs) for treatment of cryptosporidiosis in mice.

Material and Methods: Sixty-five male albino mice were infected orally with $10^{4}$ Cryptosporidium oocysts. They were grouped and treated with nanazoxid (NTZ) (100 mg/kg), C. molmol extract (500 mg/kg), and C. molmol loaded chitosan nanofibers (Cm-CsNFs) at 25, 50, and $100 \mathrm{mg} / \mathrm{kg}$. The scarification of mice was done after 5 and 10 days of treatments. Assessment of the treatments' efficacy was achieved using parasitological parameters: oocysts and trophozoites counts, and histopathological examination.

Results: C. molmol extract and Cm-CsNFs $(100 \mathrm{mg} / \mathrm{kg}$ ) significantly reduced the mean number of intestinal oocysts. All the treatment regimens significantly $(P<0.05)$ diminished the mean number of trophozoites relative to the infected non-treated group. Apparent pathological alterations in intestinal tissues were consistent with cryptosporidiosis. Cryptosporidium-induced pathological alterations were improved remarkably in Cm-CsNFs $(100 \mathrm{mg} / \mathrm{kg}$ ) group.

Conclusion: Our study highlights the efficacy of $C$. molmol as an extract or conjugated with CsNFs in declining cryptosporidiosis and attenuating Cryptosporidium-induced intestinal injury.
\end{abstract}

Keywords: Chitosan nanofibers, C. molmol, Cryptosporidium, histopathological alterations, myrrh.

Received: 28 December, 2020, Accepted: 10 February, 2021.

Corresponding Author: Azza M Fahmy, Tel.: +20 1004335729, E-mail: azzafhmy@gmail.com

Print ISSN: 1687-7942, Online ISSN: 2090-2646, Vol. 14, No. 1, April, 2021.

\section{INTRODUCTION}

Cryptosporidiosis is a principal cause of diarrhea in both humans and animals all over the world, and is caused by several species of the intestinal protozoan parasite Cryptosporidium ${ }^{[1]}$. The infection is potentially life-threatening ${ }^{[2]}$ and a significant contributor to early childhood mortality ${ }^{[3]}$. It is one of the most widespread waterborne protozoa (WBP) in developing countries ${ }^{[4]}$. Egypt has contributed to almost 1/3 (36/120) of WBP reports in Africa ${ }^{[5]}$. Cryptosporidium is a monoxenous Apicomplexan parasite, completing its entire life cycle within a single host ${ }^{[3]}$. The infectious form of the parasite, known as the oocyst, is resistant to many standard disinfectants, due to its hard wall. The small size, low infectious dosage, long-term viability, and multiple exposure routes ${ }^{[6]}$ make Cryptosporidium a very difficult pathogen to monitor. Cryptosporidium oocyst comprises four sporozoites which are released when oocysts are swallowed by the host to invade the apical intestinal epithelial cells. Then, it undergoes asexual and sexual replication processes, leading to the development of new oocysts that are expelled by the infected host ${ }^{[7]}$.

Presently, the available medications are not entirely successful against cryptosporidiosis ${ }^{[7]}$. Nitazoxanide is the only FDA-approved drug used for the treatment in immunocompetent persons, although it is not entirely effective ${ }^{[8]}$. Besides NTZ, a few other commercial medications are not FDA-approved for the treatment ${ }^{[9]}$. Thus there is a crucial need for the production of new safe and efficient therapeutic agents $^{[10]}$.

Plant extracts have advantages over prescription drugs; not only are they more cost-effective, easier to produce and process, more available, and more effective, but they also tend to have fewer adverse effects ${ }^{[11]}$. Conjugation of plant extracts into nanostructured drug delivery systems, enhanced their therapeutic properties, potency, and safety of the active entity ${ }^{[12,13]}$. C. molmol, known in folklore medicine as Myrrh, is one of the effective plants 
commonly used as an anti-parasitic. Myrrh is believed to be more effective in the prevention of infectious diseases, relying on Egyptian beliefs and culture ${ }^{[14,15]}$. Several studies have explored and established the effectiveness of $C$. molmol against various diseases such as anti-bacterial ${ }^{[16]}$, anti-inflammatory, analgesic, antihyperlipidemic ${ }^{[17]}$, and anti-cancer agent ${ }^{[18]}$ as well. Also, it has a strong and unique antibiotic activity ${ }^{[19]}$. It has been used in the treatment of hypertension ${ }^{[20]}$, respiratory infections ${ }^{[21]}$, healing wound injuries, and ulcers $^{[22]}$. C. molmol effectively treated protozoa ${ }^{[23,24]}$ and helminths ${ }^{[25-27]}$ infections. An increasing number of studies proved the safety of $C$. molmol in experimental studies at a dosage of $500 \mathrm{mg} / \mathrm{kg} /$ day $^{[28-30]}$.

Because of their unique properties, electrospun nanofibers are regarded as a promising drug delivery system for plant extracts, and electrospinning is a successful way to manufacture them ${ }^{[31]}$. The chitosan nanofiber is a remarkable material in the controlled drug delivery process. It decreases the side effects of the pharmaceutical ingredient and preserves the dosage of the drug concentration within the effective therapeutic range allowing it high potential for use in many fields ${ }^{[32]}$. Combining nanofibers with plants is a way to integrate the physical properties of the nanofibers' structure and the chemical and antiparasitic properties of the plants $^{[31]}$

Based on the proven advantages of the incorporation of chitosan nanofibers into the modern drug delivery system, the present study aimed to investigate the efficacy of $C$. molmol loaded chitosan nanofibers (Cm-CsNFs) as a curing agent of cryptosporidiosis in experimental mice.

\section{MATERIAL AND METHODS}

This case control study was conducted at Theodor Bilharz Research Institute (TBRI), Giza, Egypt, during the period from September to November 2019.

Experimental animals: The research was performed on 65 male Swiss albino mice aged 4-5 weeks and weighing 20-24 gm in Theodor Bilharz Research Institute (TBRI) in Giza, Egypt. Mice were free from any parasitic infection as determined by microscopic examination of their stools for three successive days. Animals were kept in separate laboratory cages under optimum conditions. Private laboratory mouse pellets as food and water ad libitum were also readily accessible.

Cryptosporidium oocysts: Cryptosporidium oocysts were obtained from the Animal Reproduction Research Institute (ARRI)] Giza, Egypt. The fecal samples were collected from naturally infected diarrheic calves (1-2 months old), and concentrated using the formolether concentration technique ${ }^{[33]}$. The inoculum was adjusted to infect mice orally with $10^{4}$ Cryptosporidium oocysts using esophageal tube according to Benamrouz et $a l^{[34]}$. Fecal pellets were obtained from inoculated mice individually after infection and exposed to parasitological examination using the modified ZeihlNeelsen stain $^{[35]}$ to detect Cryptosporidium spp. oocysts and to ensure that the mice were successfully infected.

Treatment: Nanazoxid (Medizen pharmaceutical industries for Utopia pharmaceuticals) was given via the oral route as a suspension $(100 \mathrm{mg} / \mathrm{kg} / \mathrm{d})$ for ten consecutive days ${ }^{[36]}$.

Preparation of $C$. molmol extract: Two hundred grams of fine powder of $C$. molmol was obtained from the local market, Cairo, Egypt, and the herbal extract preparation according to Shalaby and Hammouda ${ }^{[17]}$ was then orally administered daily to male mice at doses of $500 \mathrm{mg} / \mathrm{kg}$ body weight.

Preparation of chitosan nanofibers: The electrospinning technique following the method of Mengistu Lemma and his colleagues ${ }^{[37]}$ was used to fabricate chitosan nanofibers.

C. molmol loading on chitosan nanofibers: Preparation of $C$. molmol loaded CsNFs was conducted at three concentrations of C. molmol (25, 50, and 100 $\mathrm{mg} / \mathrm{kg}$ ) as per Ibrahim et al. ${ }^{[38]}$.

Experimental design: Mice were classified into 6 groups (I-VI), and each was divided equally into two subgroups (A and B), according to the time of scarification (5 and 10 days after treatment, respectively). Treatment began on the first day of oocyst shedding and continued for 10 consecutive days for all groups. All subgroups consisted of 5 mice in each, in addition to 5 mice that served as the normal non-infected control for histopathological study. The following table shows the studied groups.

\begin{tabular}{ll}
\hline \hline Groups & \multicolumn{1}{c}{ Characteristics } \\
\hline I & Mice infected and not treated. \\
II & Infected mice and treated with NTZ $(100 \mathrm{mg} / \mathrm{kg})$ \\
III & Infected mice and treated with C. molmol extract $(500 \mathrm{mg} / \mathrm{kg})$ \\
IV & Infected mice and treated with C. molmol loaded chitosan nanofibers (Cm-CsNFs) at a dose of $25 \mathrm{mg} / \mathrm{kg}$ body \\
& weight (BW) \\
V & Infected mice and treated with (Cm-CsNFs) at a dose of $50 \mathrm{mg} / \mathrm{kg} \mathrm{BW}$ \\
VI & Infected mice and treated with (Cm-CsNFs) at a dose of $100 \mathrm{mg} / \mathrm{kg} \mathrm{BW}$ \\
\hline \hline
\end{tabular}


Parasitological studies: After treatment, fresh fecal pellets from each mouse in the study groups were collected and labeled individually for oocyst count. Duodenal content was also obtained for trophozoite enumeration after scarification of mice. Cryptosporidium oocyst and vegetative forms were stained by modified Zeihl-Neelsen stain and examined microscopically. The number of oocysts was counted in ten high-powered fields; the arithmetic means of oocysts for each animal and then for each group of animals were determined ${ }^{[9]}$, and the same was calculated for the trophozoites. The percentage reduction in parasite count was calculated as: [(mean number of parasites in the control group - mean number of parasites in the treated group) / (mean number of parasites in the treated group)]* 100 .

Histopathological examination: A two $\mathrm{cm}$ portion of duodenum was dissected from each mouse, fixed in $10 \%$ neutral formalin then embedded in paraffin. To determine the structural alterations in the affected tissues, the obtained sections were stained with hematoxylin and Eosin (H\&E) as per Cardiff et al. ${ }^{[39]}$.

Statistical analysis: The software package used to analyze the data statistically was GraphPad Prism version 7.00 (GraphPad Software, La Jolla California USA). Data were expressed as means \pm standard error. Comparisons between the controls and experimental groups were carried out using Student's $t$-test according to Snedecor and Cochran ${ }^{[40]}$. The difference between the experimental groups was considered significant at $P<0.05$.

Ethics statement: All animals handled in the current laboratory research were used in compliance with the ethical and technical regulations of the TBRI, Giza, Egypt, on animal rights for scientific purposes. Dealing with the experimental animals was conducted according to the Internationally Valid Guidelines and the institution responsible for animal ethics.

\section{RESULTS}

Parasitological study: It was observed that NTZ significantly reduced oocysts shedding in the stool to $3.23 \times 10^{3}$ and $1.84 \times 10^{3}$, which represented about $44 \%$ and $79 \%$ reduction of oocysts, 5 days (Table 1) and 10 days after treatment (Table 2), respectively relative to infected untreated controls. This observation was significantly maintained for C. molmol extract (500 $\mathrm{mg} / \mathrm{kg}$ ) and Cm-CsNFs (100 mg/kg) with reduced mean number of intestinal oocysts to $3.4 \times 10^{3}$ and $2.84 \times 10^{3}$, reaching about $41 \%$ and $51 \%$ respectively. Inhibition of infection relative to untreated infectious control was significant $(P<0.05) 5$ days after treatment (Table 1). Reduction increased after 10 days (Table 2) where C. molmol extract ( $500 \mathrm{mg} / \mathrm{kg}), \mathrm{Cm}-\mathrm{CsNFs}$ (50 mg/kg), and Cm-CsNFs (100 mg/kg) produced a significant decrease $(P<0.05)$ in the mean counts amounting to $2.67 \times 10^{3}, 3.76 \times 10^{3}$ and $1.72 \times 10^{3}$, with a reduction of $\sim 70 \%, 58 \%$, and $81 \%$, respectively, relative to the infected non treated group. No evidence of improvement was recorded due to treatment with Cm-CsNFs at the dosage of $25 \mathrm{mg} / \mathrm{kg}(P>0.05)$, as the percent reduction was approximately $16 \%$ (Table 2 ).

The effect of treatments against Cryptosporidium vegetative forms in the intestine was depicted in tables (3 and 4). All the treatment schedules significantly $(P<0.05)$ diminished the mean number of trophozoites compared with the infected non treated group. The most obvious decline was recorded in Cm-CSNFs $(100$ $\mathrm{mg} / \mathrm{kg}$ ) representing the percent reduction of about $80 \%$ and $68 \%$ after 5 days (Table 3) and 10 (Table 4) days of treatment, respectively. While the minimum decrease in the mean number of trophozoites was observed in the infected group treated with Cm-CsNFs $(25 \mathrm{mg} / \mathrm{kg}$ ) and the percent of reductions were $43 \%$ and $27 \%$ after 5 and 10 days of treatment, respectively.

Histopathological study: Compared to the uninfected normal group (Fig. 1a), the H \& E-stained intestinal sections of the Cryptosporidium-infected control group (Fig. 1b) showed, apparent pathological alterations consistent with cryptosporidiosis. NTZ was able to diminish tissue damages without complete recovery (Fig. 1c). Treatment of the infected group with C. molmol extract $(500 \mathrm{mg} / \mathrm{kg})$ produced no marked improvement in the villus architecture (Fig. 1d). Intestinal sections of the infected treated group with $\mathrm{Cm}$-CsNFs at 25 $\mathrm{mg} / \mathrm{kg}$ (Fig. 1e) and Cm-CSNFs (50 mg/kg) (Fig. 1f) showed slight to moderate pathological changes in the intestinal sections. Compared to the infected untreated group, the histopathological injuries in intestinal

Table 1. The mean number and percentage reduction of Cryptosporidium oocyst shedding in mice after 5 days of receiving different treatment regimens.

\begin{tabular}{lccc}
\hline \multicolumn{1}{c}{ Groups } & Mean \pm SEM X $\mathbf{1 0}^{\mathbf{3}}$ & \% reduction & Significance \\
\hline Infected, non-treated (Control) & $5.80 \pm 0.23$ & & \\
NTZ $(100 \mathrm{mg} / \mathrm{kg})$ & $3.23 \pm 0.49$ & 44.19 & $\mathrm{a}$ \\
C. molmol extract $(500 \mathrm{mg} / \mathrm{kg})$ & $3.40 \pm 0.19$ & 41.29 & $\mathrm{a}, \mathrm{ns}$ \\
Cm-CsNFs $(25 \mathrm{mg} / \mathrm{kg})$ & $5.45 \pm 0.20$ & 5.97 & $\mathrm{~ns}, \mathrm{~b}$ \\
Cm-CsNFs $(50 \mathrm{mg} / \mathrm{kg})$ & $5.31 \pm 0.24$ & 8.30 & $\mathrm{~ns}, \mathrm{~b}$ \\
Cm-CsNFs $(100 \mathrm{mg} / \mathrm{kg})$ & $2.84 \pm 0.19$ & 50.96 & $\mathrm{a}, \mathrm{ns}$ \\
\hline
\end{tabular}

SEM: standard error; NTZ: Nanazoxid; Cm-CsNFs: C. molmol loaded on chitosan nanofibers. Significant if $P<0.05$. a: Significant difference in comparison to the infected control group; b: Significant difference in comparison to NTZ treated group; ns: Non-significant. 
tissue sections were reduced and the improvement of villi structure was remarkably noticed. Most of the villi were intact with their tall columnar epithelium and mild inflammatory cells, along with improved degenerative changes in the glands (Fig. 1g) in the group of infected mice and treated with Cm-CsNFs at $100 \mathrm{mg} / \mathrm{kg}$.

Table 2. The mean number and the percentage reduction of Cryptosporidium oocyst shedding in mice after 10 days of receiving different treatment regimens.

\begin{tabular}{|c|c|c|c|}
\hline Groups & Mean \pm SEM X $10^{3}$ & $\%$ reduction & Significance \\
\hline Infected, non-treated (Control) & $8.96 \pm 0.45$ & & \\
\hline NTZ $(100 \mathrm{mg} / \mathrm{kg})$ & $1.84 \pm 0.59$ & 79.43 & a \\
\hline C. molmol extract (500 mg/kg) & $2.67 \pm 0.23$ & 70.15 & a, ns \\
\hline Cm-CsNFs $(25 \mathrm{mg} / \mathrm{kg})$ & $7.50 \pm 0.36$ & 16.25 & ns, b \\
\hline Cm-CsNFs (50 mg/kg) & $3.76 \pm 0.31$ & 58.05 & $a, b$ \\
\hline Cm-CsNFs (100 mg/kg) & $1.72 \pm 0.18$ & 80.75 & a, ns \\
\hline
\end{tabular}

SEM: standard error; NTZ: Nanazoxid; Cm-CsNFs: C. molmol loaded on chitosan nanofibers. Significant if $P<0.05$. a: Significant difference in comparison to the infected control group; b: Significant difference in comparison to NTZ treated group; ns: Non-significant.

Table 3. The mean number and the percentage reduction of Cryptosporidium trophozoites in intestinal contents in mice after 5 days of receiving different treatment regimens.

\begin{tabular}{lccc}
\hline \multicolumn{1}{c}{ Groups } & Mean \pm SEM X $\mathbf{1 0}^{\mathbf{3}}$ & \% reduction & Significance \\
\hline Infected, non-treated (Control) & $17.60 \pm 0.81$ & & \\
NTZ (100 mg/kg) & $6.80 \pm 0.63$ & 61.36 & $\mathrm{a}$ \\
C. molmol extract (500 mg/kg) & $7.00 \pm 0.70$ & 60.23 & $\mathrm{a}, \mathrm{ns}$ \\
Cm-CsNFs (25 mg/kg) & $10.00 \pm 0.72$ & 43.18 & $\mathrm{a}, \mathrm{b}$ \\
Cm-CsNFs (50 mg/kg) & $7.60 \pm 0.65$ & 56.82 & $\mathrm{a}, \mathrm{ns}$ \\
Cm-CsNFs (100 mg/kg) & $3.60 \pm 0.51$ & 79.55 & $\mathrm{a}, \mathrm{ns}$ \\
\hline \hline
\end{tabular}

SEM: standard error; NTZ: Nanazoxid; Cm-CsNFs: C. molmol loaded on chitosan nanofibers. Significant if $P<0.05$. a: Significant difference in comparison to the infected control group; b: Significant difference in comparison to NTZ treated group; ns: Non-significant. .

Table 4. The mean number and the percentage reduction of Cryptosporidium trophozoites in intestinal contents in mice after 10 days of receiving different treatment regimens.

\begin{tabular}{|c|c|c|c|}
\hline Groups & Mean \pm SEM X $10^{3}$ & $\%$ reduction & Significance \\
\hline Infected, non-treated (Control) & $36.80 \pm 1.88$ & & \\
\hline NTZ $(100 \mathrm{mg} / \mathrm{kg})$ & $15.20 \pm 2.04$ & 58.70 & a \\
\hline C. molmol extract (500 mg/kg) & $17.80 \pm 2.08$ & 51.63 & a, ns \\
\hline Cm-CsNFs $(25 \mathrm{mg} / \mathrm{kg})$ & $26.80 \pm 0.86$ & 27.17 & $a, b$ \\
\hline Cm-CsNFs (50 mg/kg) & $19.80 \pm 0.86$ & 47.28 & a, ns \\
\hline Cm-CsNFs $(100 \mathrm{mg} / \mathrm{kg})$ & $11.80 \pm 0.37$ & 67.93 & $\mathrm{a}, \mathrm{ns}$ \\
\hline
\end{tabular}

SEM: standard error; NTZ: Nanazoxid; Cm-CsNFs: C. molmol loaded on chitosan nanofibers. Significant if $P<0.05$. a: Significant difference in comparison to the infected control group; b: Significant difference in comparison to NTZ treated group; ns: Non-significant. .
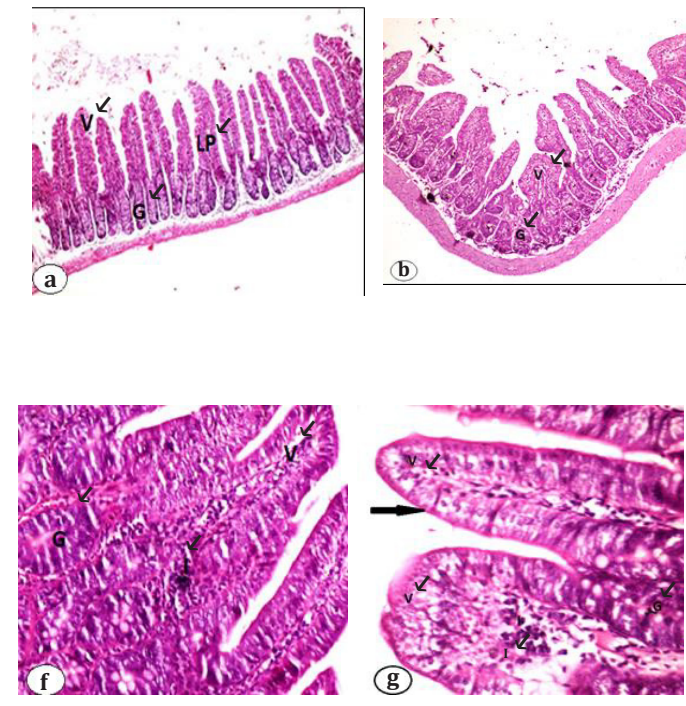
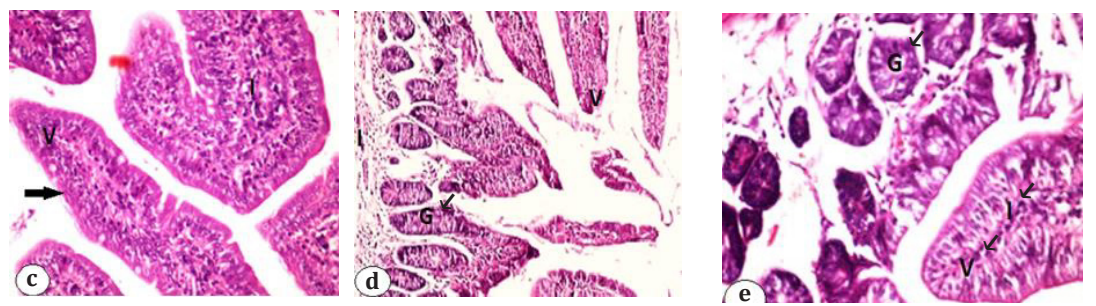

Fig. 1. Intestinal sections of mice stained with $\mathrm{H} \& \mathrm{E}$ (a-g). (a) Photomicrograph of intestinal tissue of uninfected group showing intact villi (V), lamina propria (LP), and goblet cell (G), (X40); (b) Infected mice displayed shortening, fusion and blunting of the villi with irregular brush border and reduction of goblet cells, (X40); (c) Infected mice and treated with NTZ showing improvement in the villi structure (V), and near normal columnar epithelium (arrow), (X200); (d) Infected mice treated with C. molmol showing disturbed villous architecture (V), and reduction in goblet cells (G), (X 100); (e) Infected mice treated with $\mathrm{Cm}-\mathrm{CsNFs}$ at $25 \mathrm{mg} / \mathrm{kg}$ showing moderate pathological alterations, where many glands $(\mathrm{G})$ display degenerative changes and moderate inflammatory cells (I), (X 200); (f) Infected mice treated with Cm-CsNFs at $50 \mathrm{mg} / \mathrm{kg}$ showing mild inflammatory cells (I), where intact glands (G) with many villi (V) could be detected, (X 200); (g) Iinfected mice treated with Cm-CsNFs at $100 \mathrm{mg} / \mathrm{kg}$ showing remarkable improvement, where most of the villi are intact (arrow) with their tall columnar epithelium, mild inflammatory (I) cells in the core of the villi (V), together with mild degenerative changes in the glands (G), (X 400). 


\section{DISCUSSION}

The findings of the current investigation revealed that NTZwassuccessful in reducingoocystshedding, intestinal trophozoites and tissue damage, but did not completely dispose of Cryptosporidium infection throughout the trial periods. Over the range of concentration dosages, $\mathrm{Cm}$-CsNFs triggered significant destruction of oocysts at $100 \mu \mathrm{g} / \mathrm{ml} 5$ days post-treatment, while $50 \mu \mathrm{g} /$ $\mathrm{ml}$ was the minimal concentration dose that had a significant destructive rate on the oocysts 10 days after treatment in experimental mice. Regarding the impact of the treatments on the intestinal vegetative forms, interestingly, all the treatments significantly diminished the mean counts all through the experimental periods.

The noted observation emerging from the compared data was that $\mathrm{Cm}-\mathrm{CsNFs}(100 \mathrm{mg} / \mathrm{kg}$ ) is more effective against oocyst and trophozoite of Cryptosporidium than NTZ, which is the mainline, standard treatment for infection in adults and children ${ }^{[8]}$. Also the chitosan loaded C. molmol gave better result than the sole extract C. molmol despite the high dose used ( $500 \mathrm{mg} / \mathrm{kg}$ ). This is because plant extracts loaded in nanostructured drug delivery systems have the advantages to improve their therapeutic effectiveness and extension of their antiparasitic activity ${ }^{[41]}$ because of their smaller particle size, larger surface area, and faster dissolution rate ${ }^{[42]}$.

Existence of the tannins phenolic compound as one of the components of Commiphora spp. ${ }^{[43,44]}$, is accountable for its antiprotozoal activity ${ }^{[23,24,45,46]}$. Tannins bind proteins to mucous surfaces rendering them less permeable with poor absorption due to the protective coating of coagulated protein, making the expulsion of parasites easier ${ }^{[43]}$. The conjugation of $C$. molmol into the CsNFs permitted the adsorption of $C$. molmol to the surface of the wall of the oocysts ${ }^{[47,48]}$, contributing to a shift in its integrity and permeability leading to their damage ${ }^{[49]}$. However, the additive effects of $C$. molmol and CsNFs conjugation observed in the present study may be due to the different synergistic mechanisms of action of both substances.

Dislodging of brush border and asymmetrical loss of epithelial cells with shortening and fusion of villi reflects the pathological alterations in response to cryptosporidiosis infection $^{[50,51]}$. These progressions are brought about by trophozoite of the Cryptosporidium and the significant infiltration of lymphocytes ${ }^{[52,53]}$. The improvement in the pathological picture was indicated by the recuperation of the brush border to regular structure in response to treatment with NTZ and Cm-CsNFs (100 $\mathrm{mg} / \mathrm{kg}$ ). This can be attributed to the decreased number of oocysts (Tables 1 and 2) and trophozoites (Tables 3 and 4), and/or reduction of cytokines and inflammatory cells production $^{[51,54]}$.

Reduced immune cell production is attributed to the impact of the flavonoids which are one of the chemical ingredients of $C$. molmol ${ }^{[43,44]}$ with their known antiinflammatory activities ${ }^{[55,56]}$. All in all, this study demonstrated the restoration of the normal structures of villi and the reduction of oocysts shedding in the stool and duodenal content of experimental animals in response to treatment with CsNFs loading $C$. molmol $(100 \mathrm{mg} / \mathrm{kg})$. Moreover, the superiority of the effect of nano form structure of $C$. molmol over NTZ, the drug of choice against cryptosporidiosis was observed.

In conclusion, our study highlights the role of $C$. molmol (at dosages of $500 \mathrm{mg} / \mathrm{kg}$ and its conjugation with CsNFs in various dose regimens) in declining Cryptosporidium infestation and attenuating Cryptosporidium-induced intestinal damage. Further investigations should be applied before approving C. molmol either alone or loaded in a nanostructured drug delivery system for the battle against this disease of zoonotic importance. Our findings may likewise form the basis for further study of related infections in animals and man.

Acknowledgments: We appreciate Dr. Sahar Darwish, head of the Pathology Department, National Organization for Drug Control and Research, Egypt for her technical assistance of pathological methodology and valuable comments.

Authors' contributions: Fahmy AM designed the study, analyzed statistical data, drafted, and reviewed the manuscript. Fahmy ZH, Aly EA, and Elshenawy AM contributed to the study design, conducted the laboratory investigations, and drafted the manuscript El-Wakil EA performed the plant extraction. All authors approved the final version.

Conflict of interest: The authors declare that there is no conflict of interest.

Financial statement: No financial support was provided.

\section{REFERENCES}

1. Innes EA, Chalmers RM, Wells B, Pawlowic MC. A one health approach to tackle cryptosporidiosis: A review. Trends Parasitol 2020; 36(3):290-303.

2. Mmbaga BT, Houpt ER. Cryptosporidium and Giardia infections in children: A review. Pediatr Clin North Am 2017; 64(4):837-850.

3. Pawlowic MC, Somepalli M, Sateriale A, Herbert GT, Gibson AR, Cuny GD, et al. Genetic ablation of purine salvage in Cryptosporidium parvum reveals nucleotide uptake from the host cell. Proc Natl Acad Sci 2019; 116(42):21160-21165.

4. Efstratiou A, Ongerth JE, Karanis P. Waterborne transmission of protozoan parasites: Review of worldwide outbreaks: An update 2011-2016. Water Res 2017; 114:14-22.

5. Ahmed SA, Guerrero Flórez M, Karanis P. The impact of water crises and climate changes on the transmission 
of protozoan parasites in Africa. Pathog Glob Health 2018; 112(6):281-293.

6. Omarova A, Tussupova K, Berndtsson R, Kalishev M, Sharapatova K. Protozoan parasites in drinking water: A system approach for improved water sanitation and hygiene in developing countries. Int J Environ Res Public Health 2018; 15(3):1-18.

7. Marzook NB, Sateriale A. Crypto-Currency: Investing in new models to advance the study of Cryptosporidium infection and immunity. Front Cell Infect Microbiol 2020; 10:1-7.

8. Jin Z, Ma J, Zhu G, Zhang H. Discovery of novel anticryptosporidial activities from natural products by in vitro high-throughput phenotypic screening. Front Microbiol 2019; 10:1-11.

9. Madbouly TN, Salah A, Yousof HA, El-Sayed SH, Younis AI, Negm MSI. Atorvastatin repurposing for the treatment of cryptosporidiosis in experimentally immunosuppressed mice. Exp Parasitol 2017; 181:5769.

10. Mammeri M, Chevillot A, Thomas M, Polack B, Julien C, Marden J, et al. Efficacy of chitosan, a natural polysaccharide, against Cryptosporidium parvum in vitro and in vivo in neonatal mice. Exp Parasitol 2018; 194:1-8.

11. Calixto JB. The role of natural products in modern drug discovery. An Acad Bras Cienc 2019; 91(3): e20190105.

12. Natarajan S, Chandran S, Vinukonda A, Rajan D. Green tea catechin loaded nano delivery systems for the treatment of pandemic diseases. Asian J Pharm Clin Res 2019; 12(5):1-7.

13. Sandhiya V, Ubaidulla U. A review on herbal drug loaded into pharmaceutical carrier techniques and its evaluation process. Futur J Pharm Sci 2020; 6(1):5167.

14. Massoud A, Massoud A, Salama O, El Sisi S. Preliminary study of therapeutic efficacy of a new fasciolicidal drug derived from Commiphora molmol (myrrh). Am J Trop Med Hyg 2001; 65(2):96-99.

15. Basyoni MMA, El-Sabaa AAA. Therapeutic potential of myrrh and ivermectin against experimental Trichinella spiralis infection in mice. Korean J Parasitol 2013; 51(3):297-304.

16. Hana DB, Kadhim HM, Jasim GA, Latif QN. Antibacterial activity of Commiphora molmol extracts on some bacterial species in Iraq. Sch Acad J Pharm 2016; 5(12):406-412.

17. Shalaby M, Hammouda A. Analgesic, antiinflammatory, and anti-hyperlipidemic activities of Commiphora molmol extract (Myrrh). J Intercult Ethnopharmacol 2014; 3(2):56-62.

18. Chen Y, Zhou C, Ge Z, Liu Y, Feng W, Li S, et al. Composition, and potential anticancer activities of essential oils obtained from myrrh and frankincense. Oncol Lett 2013; 6(4):1140-1146.

19. Bhattacharjee MK, Alenezi T. Antibiotic in myrrh from Commiphora molmol preferentially kills nongrowing bacteria. Futur Sci OA 2020; 6(4): FSO458.
20. Abdul-Ghani AS, Amin R. Effect of aqueous extract of Commiphora opobalsamum on blood pressure and heart rate in rats. J Ethnopharmacol 1997; 57(3):219222.

21. Atta AH, Alkofahi A. Anti-nociceptive and antiinflammatory effects of some Jordanian medicinal plant extracts. J Ethnopharmacol 1998; 60(2):117124.

22. Vega-Cázarez CA, Sánchez-Machado DI, LópezCervantes J. Overview of electrospinned chitosan nanofiber composites for wound dressings. In: ChitinChitosan-Myriad Functionalities in Science and Technology. InTech; 2018.

23. El-Sherbiny GM, El Sherbiny ET. The effect of Commiphora molmol (Myrrh) in treatment of trichomoniasis vaginalis infection. Iran Red Crescent Med J 2011; 13(7):480-486.

24. Mahmoud SS, Aly E, Fahmy ZH, Shenawy A El. Effect of Commiphora molmol (Myrrh) extract on mice infected by Giardia lamblia. J Biosci Med 2019; 7(10):50-60.

25. EL-Malky MA, Lu S, El-Beshbishi SN, Saudy NS, Ohta N. Effect of Mirazid in Schistosoma japonicum-infected mice: Parasitological and pathological assessment. Parasitol Res 2013; 112(1):373-377.

26. Massoud AM, Shalaby HAM, El Khateeb RM, Mahmoud MS, Kutkat MAA. Tegumental histological effects of Mirazid $^{\circledR}$ and myrrh volatile oil on adult Fasciola gigantica. Asian Pac J Trop Biomed 2013; 3(6):501504.

27. Abdelaal MMO, Brennan GP, Abdel-Aziz A, Fairweather I. Ultrastructural changes to the tegumental system and gastrodermal cells of adult Fasciola hepatica following treatment in vivo with a commercial preparation of myrrh (Mirazid). J Helminthol 2017; 91(6):672-685.

28. Abdul-Ghani R, Loutfy $N$, Sheta $M$, Hassan A. Chemotherapeutic efficacy of a natural combination in the treatment of mansonic schistosomiasis: an experimental study. Res Rep Trop Med 2011; 1:1-7.

29. Aziz M, Kazzaz A. Effect of Commiphora molmol extract (Mirazid) on the tegument of Schistosoma mansoni and serum acetylcholinesterase activity in infected mice. Saudi J Heal Sci 2017; 6:57-61.

30. Kamil M, Abdalla TM. Biochemical, anti-diarrhoeal and anti-gastric ulcer activities of Commiphora myrrha. Biomed J Sci Tech Res 2019; 19(3):14349-14351.

31. Fatehi $\mathrm{P}$, Abbasi M. Medicinal plants used in wound dressings made of electrospun nanofibers. J Tissue Eng Regen Med 2020; 14(11):1527-1548.

32. AL-Jbour ND, Beg MD, Gimbun J, Alam AKMM. An overview of chitosan nanofibers and their applications in the drug delivery process. Curr Drug Deliv 2019; 16(4):272-294.

33. Waldman E, Tzipori S, Forsyth JR. Separation of Cryptosporidium species oocysts from feces by using a percoll discontinuous density gradient. J Clin Microbiol 1986; 23(1):199-200.

34. Benamrouz S, Guyot K, Gazzola S, Mouray A, Chassat T, Delaire B, et al. Cryptosporidium parvum infection 
in SCID mice infected with only one oocyst: qPCR assessment of parasite replication in tissues and development of digestive cancer. Plos One 2012; 7(12):1-7.

35. Tahvildar-Biderouni F, Salehi N. Detection of Cryptosporidium infection by modified ziehl-neelsen and PCR methods in children with diarrheal samples in pediatric hospitals in Tehran. Gastroenterol Hepatol Bed Bench 2014; 7(2):125-130.

36. Sadek G, El Aswad W. Role of COX-2 in pathogenesis of intestinal cryptosporidiosis and effect of some drugs on treatment of infection. Res J Parasitol 2014; $9(2): 21-40$.

37. Mengistu Lemma S, Bossard F, Rinaudo $M$. Preparation of pure and stable chitosan nanofibers by electrospinning in the presence of poly (ethylene oxide). Int J Mol Sci 2016; 17(11):1790-1806.

38. Ibrahim S, Sayed HM, EL-Rafei AM, El Amir A, Ismail $\mathrm{M}$, Allam NK. Improved genistein loading and release on electrospun chitosan nanofiber blends. J Mol Liq 2016; 223:1056-1061.

39. Cardiff RD, Miller CH, Munn RJ. Manual hematoxylin and eosin staining of mouse tissue sections. Cold Spring Harb Protoc 2014; 2014(6):655-658.

40. Snedecor GW, Cochran WG. Statistical Methods. $7^{\text {th }}$ ed. Iowa State University Press; 1980.

41. Gondim BLC, Oshiro-Júnior JA, Fernanandes FHA, Nóbrega FP, Castellano LRC, Medeiros ACD. Plant extracts loaded in nanostructured drug delivery systems for treating parasitic and antimicrobial diseases. Curr Pharm Des 2019; 25(14):1604-1615.

42. Priotti J, Codina AV, Leonardi D, Vasconi MD, Hinrichsen LI, Lamas MC. Albendazole microcrystal formulations based on chitosan and cellulose derivatives: physicochemical characterization and in vitro parasiticidal activity in Trichinella spiralis adult worms. AAPS Pharm Sci Tech 2017; 18(4):947-956.

43. Baghdadi HB, Al-Mathal EM. Anti-coccidial effect of Commiphora molmol in the domestic rabbit (Oryctolagus cuniculus domesticus L.). J Egypt Soc Parasitol 2010; 40(3):653-668.

44. Okwute SK, Ochi IO. Phytochemical analysis and cytotoxic activity of the root extract of Commiphora africana (Caesalpiniaceae). J Pharmacogn Phytochem 2017; 6(6):451-454.

45. Fathy FM. Effect of mirazid (Commiphora molmol) on experimental giardiasis. J Egypt Soc Parasitol 2011; 41(1):155-177.
46. Abouel-Nour MF, Hamada SF, Kadhim SJ. Effect of some natural products and metronidazole on immunity against Entamoeba histolytica infection in mice. J Egypt Soc Parasitol 2017; 47(3):549-558.

47. Bell IR, Ives JA, Wayne BJ. Nonlinear effects of nanoparticles: Biological variability from hormetic doses, small particle sizes, and dynamic adaptive interactions. Dose-Response. 2014; 12(2):202-232.

48. Barhoum A, Bechelany M, Makhlouf ASH, eds. Handbook of Nanofibers. Springer International Publishing; 2019.

49. Ahmed SA, El-Mahallawy HS, Karanis P. Inhibitory activity of chitosan nanoparticles against Cryptosporidium parvum oocysts. Parasitol Res 2019; 18(7):2053-2063.

50. Al-Mathal EM, Alsalem AM. Pomegranate (Punica granatum) peel is effective in a murine model of experimental Cryptosporidium parvum. Exp Parasitol 2012; 131(3):350-357.

51. Hemphill A, Müller N, Müller J. Comparative pathobiology of the intestinal protozoan parasites Giardia lamblia, Entamoeba histolytica, and Cryptosporidium parvum. Pathogens 2019; 8(3):116.

52. Soufy H, El-Beih NM, Nasr SM, Abd El-Aziz TH, Khalil FAM, Ahmed YF. Effect of Egyptian Propolis on cryptosporidiosis in immunosuppressed rats with special emphasis on oocysts shedding, leukogram, protein profile and ileum histopathology. Asian Pac J Trop Med 2017; 10(3):253-262.

53. El Shafei OK, Saad AGE, Harba NM, Sharaf OF, Samaka RM FS. Therapeutic effect of phenyl vinyl sulfone and nitazoxanide on experimentally infected mice with cryptosporidiosis. Menoufia Med J 2018; 31:786-794.

54. Cheng YW, Cheah KP, Lin CW, Li JS, Yu WY, Chang ML, et al. Myrrh mediates haem oxygenase-1 expression to suppress the lipopolysaccharide-induced inflammatory response in RAW264.7 macrophages. J Pharm Pharmacol 2011; 63(9):1211-1218.

55. Ginwala R, Bhavsar R, GI, Jain P, Khan ZK. Potential role of flavonoids in treating chronic inflammatory diseases with a special focus on the anti-inflammatory activity of Apigenin. Antioxidants 2019; 8(2):1-28.

56. Choy KW, Murugan D, Leong X-F, Abas R, Alias A, Mustafa MR. Flavonoids as natural anti-inflammatory agents targeting nuclear factor-Kappa $\mathrm{B}(\mathrm{NF} \kappa \mathrm{B})$ signaling in cardiovascular diseases: A mini-review. Front Pharmacol 2019; 10:1-8. 